\title{
Antigen KI-67
}

National Cancer Institute

\section{Source}

National Cancer Institute. Antigen KI-67. NCI Thesaurus. Code C17675.

Antigen $\mathrm{KI}-67$ protein (3256 aa, 359 kDa) is encoded by the human MKI67 gene. This protein is required for cell proliferation. 